\title{
Retraction Note to: Predicting the effects of nanoparticles on early age compressive strength of ash-based geopolymers by artificial neural networks
}

\author{
Shadi Riahi ${ }^{1} \cdot$ Ali Nazari $^{1}$ \\ Published online: 15 June 2020 \\ (C) Springer-Verlag London Ltd., part of Springer Nature 2020
}

\section{Retraction Note to: Neural Comput \& Applic (2019) 31:743-750 https://doi.org/10.1007/s00521-012-1085-0}

The Editor-in-Chief has retracted this article [1] because it significantly overlaps with a number of articles including those that were under consideration at the same time [2-4] and previously published articles [5, 6]. Additionally, the article shows evidence of peer review manipulation. The authors have not responded to any correspondence regarding this retraction.

\section{References}

1. Riahi, S., Nazari, A. Predicting the effects of nanoparticles on early age compressive strength of ash-based geopolymers by artificial neural networks. Neural Comput Appl 31, 743-750 (2019). https://doi.org/10.1007/s00521-012-1085-0
2. Nazari, A., Hajiallahyari, H., Rahimi, A. et al. Prediction compressive strength of Portland cement-based geopolymers by artificial neural networks. Neural Comput Appl 31, 733-741 (2019). https://doi.org/10.1007/s00521-012-1082-3

3. Nazari, A., Abdinejad, V.R. Artificial neural networks for prediction Charpy impact energy of Al6061/SiCp-laminated nanocomposites. Neural Comput Appl 23, 801-813 (2013). https://doi.org/ 10.1007/s00521-012-0996-0

4. Nazari, A. Prediction water absorption resistance of lightweight geopolymers by artificial neural networks. Neural Comput Appl 31, 759-766 (2019). https://doi.org/10.1007/s00521-012-1136-6

5. Nazari, A. Artificial neural networks for prediction compressive strength of geopolymers with seeded waste ashes. Neural Comput Appl 23, 391-402 (2013). https://doi.org/10.1007/s00521-0120931-4

6. Nazari, A. Artificial neural networks application to predict the compressive damage of lightweight geopolymer. Neural Comput Appl 23, 507-518 (2013). https://doi.org/10.1007/s00521-0120945-y

Publisher's Note Springer Nature remains neutral with regard to jurisdictional claims in published maps and institutional affiliations.
The original article can be found online at https:// doi.org/10.1007/s00521-012-1085-0.

\section{Ali Nazari}

alinazari84@aut.ac.ir

1 Department of Materials Science and Engineering, Saveh Branch, Islamic Azad University, Saveh, Iran 